\title{
'My Verses Are the Children of My Blood': Autobiography in the Poetry of Kostas Karyotakis
}

\author{
Iakovos Menelaou \\ King's College London, UK
}

Received: 29-04-2017

Accepted: 27-05-2017

Published: 31-07-2017

doi:10.7575/aiac.ijclts.v.5n.3p.5

URL: http://dx.doi.org/10.7575/aiac.ijclts.v.5n.3p.5

\begin{abstract}
Kostas Karyotakis (1896-1928) is one of the most important Modern Greek poets. His poetry not only influenced several other poets, but it also attracted critics' interest. Former critics dealt with Karyotakis' poetry and spoke about the relation between life and work in his poems. Nevertheless, they did not analyse extensively certain poems, which reflect clearly the poet's personal experience. In addition, other critics attempted to analyse and see Karyotakis' poems as independent entities, isolated from the poet's life. While the results of such an approach were interesting, indeed, in fact they do not show the real meaning of the poems. Although such theories are useful and productive, when reading poets who made their life an important part of their poetry, biography is a key element for the interpretation of their works; thus a New Historicism approach is preferred. My purpose in this paper is to show the close relation between life and work in Karyotakis' poetry through a parallel focus on life and poetry. Going beyond the results of previous critique, I intend to show how Karyotakis' poetry alludes to his personal experience.
\end{abstract}

Keywords: Modern Greek Poetry, Autobiography, New Historicism, Literary Theory

\section{Introduction}

Kostas Karyotakis was born in 1896 in Tripoli in Greece. In 1913, he graduated from high school and went to Athens to study law. In the same year, Karyotakis met Anna Skordyli with whom he had an affair until 1915, when Skordyli married another man. Possibly, the poet kept in communication with her after her marriage. In 1917, Karyotakis was awarded his degree and three years later, in 1920, he was appointed as government clerk; a position he had until his death in 1928. In 1922, he met the poet Maria Polydouri and they had a passionate affair. In July 1928, at the age of 32 , Karyotakis committed suicide by shooting himself.

Karyotakis published many poems in periodicals, while he also published three poetic collections: $O$ IIóvos $\tau o v$

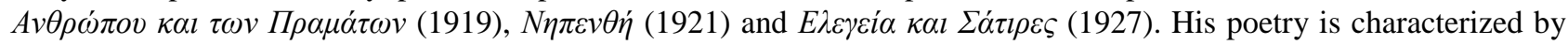
pessimism and nihilism and expresses ennui, without any hope of escape from a boring world. Pain and sadness are two permanent elements in the Karyotakian view of the world.

Dimaras (2001) believed that Karyotakis' poetry is characterized by 'honesty', since the poet includes personal experience in his work. Dimaras also considered the poet's suicide a confirmation of the identification between life and work. ${ }^{i}$ Like Dimaras, Theotokas (2001) believed that Karyotakis attempted to attract his readers, through his personal tragedy rather than his talent. ${ }^{\text {ii }}$

In fact, Dimaras and Theotokas never liked Karyotakis' poetry and they used, indirectly, this identification between life and poetry, as an argument against him. However, one could say that such an argument lacks any justification, since identification between life and work does not necessarily devalue the work. Their surmise that Karyotakis' poems frequently revolve around personal experience is indeed true, but this is not a reason to say that his poetry is not important.

Others also focus on the relation between life and work in Karyotakis' poems, in a more neutral critic. Kapsomenos (1998), for instance, asserts that Karyotakis' work, and especially his prose works of the last period, is an obvious testimony to the relation between life and work. ${ }^{\text {iii }}$ Also, Tziovas (1998) notes that Karyotakis' suicide indicates the

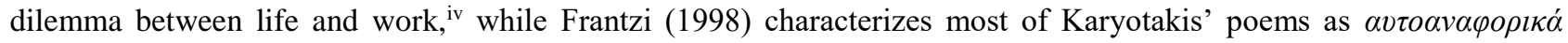
(self-referential). ${ }^{\mathrm{v}}$

Agras (2001), who acknowledges Karyotakis' skills in poetry, says about this relation between life and work:

For a real poet, and moreover for a representative poet, life and poetry become one thing. For a real poet, his work is part of his body. [...] His art is his life and his life is his art. [...] His poetry - it had already come to an end before his suicide. [...] Suicide had already become an issue in his poetry. If Karyotakis had survived, the man would have survived, but not the poet. And who knows how the man could have survived. ${ }^{\text {vi }}$

Agras asserts that the identification between life and work is a characteristic of a real poet, as Karyotakis is. In implying

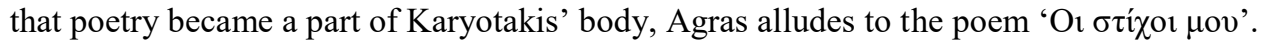


As the purpose of this paper is to show that biographical background helps readers in the analysis of Karyotakis' poetry, a New Historicism approach is suggested. New Historicism emerged in 1980s (Eagleton 1996, 2013) and it was an attempt to reject all theories which refuse to look at the poet's biography or any other relevant circumstances, ${ }^{\text {vii }}$ such theories as Russian Formalism, Semiotics and Post-Structuralism.

New Historicism arose under the influence of Foucault's writings (Eagleton 1996, 2013) and his discussions of Renaissance cultural history. ${ }^{\text {viii }}$ It redirects attention to social, political and any other circumstances which relate to the writing of a work including the life of the author. Greenblatt (2005, Robson 2007), who is one of the most important representatives of New Historicism, believes that if we want to find the meaning of texts, we should reconstruct the situation in which they were produced. ${ }^{\mathrm{ix}}$

Of course, New Historicism is not always the ideal approach in literature. Theories like Russian Formalism, Semiotics and Post-Structuralism helped in research and they also constitute a proper method for the analysis of certain texts. Nevertheless, when we read poets like Karyotakis, that we know biography is reflected clearly in his work, we cannot ignore biographical information or other social and political circumstances, as this is frequently the foundation of the poems.

Besides, the prospective reader of Karyotakis needs to have in mind the important distinction (Stephanopoulou 1998)

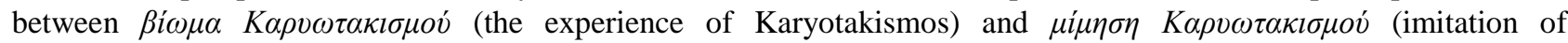
Karyotakismos). ${ }^{\mathrm{x}}$ What makes Karyotakis different compared to other poets of his generation is the experience of Karyotakismos which was adopted and imitated by other poets. However, while Karyotakis lived the depression of Karyotakismos, other poets imitated the climate of Karyotakismos, which is not just an ephemeral craze as Strasburger (2015) suggested. ${ }^{x i}$ In the absence of this distinction, there is the risk to see Karyotakis as one of the many poets who wrote in a depressive atmosphere, fashionable in 1920s Greece.

\section{Karyotakis as Soldier}

'O Mi $\chi \alpha \lambda$ ió $\zeta$ 'xii is a poem about the experience of a village boy in the army and it is included in Karyotakis' last poetic

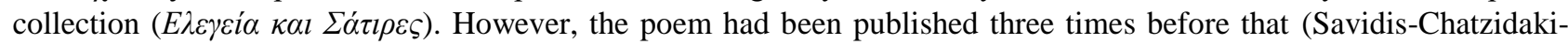
Mitsou 1989), first in 1919. xiii

The poem consists of three stanzas of six lines and is written in iambics. ${ }^{\text {iv }}$ In all stanzas we have the rhyme scheme ABACBC. As the title suggests, Michalios is the central figure of the poem. He is a young man from a village who is recruited to serve in the army against his will. His main concern is to return to his village, far from any military obligation. In the first stanza, we have the hero's recruitment along with two other young men, and his statement that he wants to return to his village. In the second stanza, the poet describes the adventure of Michalios in hospital and again his desire to go home. Finally, in the last stanza, Michalios dies and we have the description of his funeral. The poem ends with a comic scene, since Michalios' companions left his leg sticking out of the grave.

Following the principles of Semiotics, Benatsis (2004) provides us with an interesting analysis of the poem. ${ }^{\mathrm{xv}}$ He focuses only on what we have in the poem, setting aside any biographical information. According to Benatsis, the use of

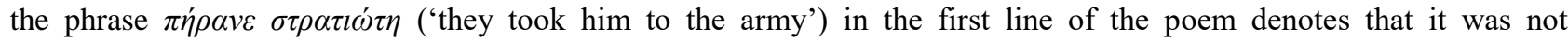
Michalios' wish to serve to the army, but something compulsory which he could not avoid. Benatsis concludes that the result of this situation is hero's inability to feel comfortable in his new life:

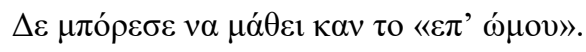

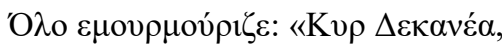

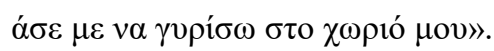

In the above lines, Michalios appears to be unable to learn even the most basics of military life.

Benatsis also states that the result is absolutely negative for Michalios, since he dies in hospital without having seen any fight. Although $\alpha \gamma \omega$ v (fight) is absent from the poem, the hero's death and wish to return to his village, implies that we have a contrast between person and army and the person is the loser. The last stanza of the poem indicates how Michalios, even after his death, persists in being against the army:

\section{А \\ $\mu \alpha \tau$

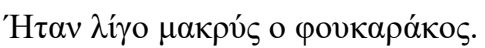

Benatsis says that Michalios' companions have not buried him properly, since his leg is sticking out of the grave. In this comical way, Karyotakis tries to make clear that Michalios had nothing to do with military life and that his desire was to return to his village.

Summarizing, Benatsis states that Michalios' leg plays an important role, since it shows that the hero could not adapt to military rules. As a result, he states that we have a clear case of contradiction between 'part to whole' ( $\mu \varepsilon \dot{\varepsilon} \rho \operatorname{cov} \pi \rho \circ \varsigma$ $o ́ \lambda o)$ : 'part' is Michalios' leg and 'whole' his body. This contradiction shows that further the ironical climate of the whole scene, $o \lambda o ́ \tau \eta \tau \alpha$ (completion) is not successful, since the leg acts independently from the rest of the body. In other words, through the model 'part to whole', we have two results: irony and absence of the completion. ${ }^{\text {xvi }}$

Benatsis' approach is very interesting, but without any extended development of this irony, Michalios becomes the object of Karyotakian satire. As the relation 'part to whole' is used by Karyotakis in the poem to show irony and 
absence of $o \lambda o ́ \tau \eta \tau \alpha$, Michalios is the 'victim' of this ironic attack. In short, if Michalios is the hero of the poem, and indeed he is, then the irony of Karyotakis is, inevitably, directed at Michalios.

Consequently, the questions that arise are: What are Karyotakis' motives to attack Michalios? And moreover, why did he choose a village boy to be the object of this attack? Does Karyotakis want to denote his antipathy for village boys, in general? Focus on the poet's biography protects him from such accusations of antipathy towards village boys or people like Michalios who is the apparent target of the irony.

In 1918, Karyotakis was called up, but he got a temporary postponement from his military obligations, hoping for a permanent discharge from the army. ${ }^{\text {xii }}$ Interestingly, Karyotakis' recruitment took place only one year before the first

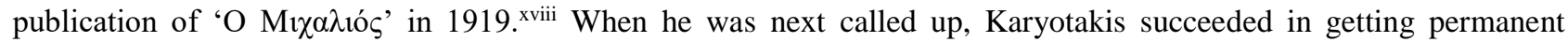
discharge. In July 1920, he was kept in a military hospital, where they found that he had a heart problem. On 22 August 1920, when he left hospital, Karyotakis moved to Chania waiting for his discharge; on 18 September, he was discharged from any military obligation because of health reasons (Savidis-Chatzidaki-Mitsou 1989). ${ }^{\text {xix }}$ Finally, in June 1921, he was officially considered unable to serve in the army. ${ }^{\mathrm{xx}}$

Karyotakis' correspondence illustrates his desire not to serve in the army. In a letter of February 1920, he writes to his close friend Sakellariades:

I read in a newspaper yesterday, that there is an order for those who were discharged in 1919 and they should appear in three days. When you receive my letter, I would appreciate if you could go and ask the military office whether this order includes students of Philology and if I could have an exemption, because I am clerk. You must never mention my name. If I have to come, telegraph or write to me. Let us see what will happen. Hell! Will they never leave me alone? ?xi $^{x}$

In the letter, Karyotakis is obviously opposed to the idea of the army and plans ways to avoid it. There is further evidence in a letter to Sakellariadis, again, of July 1920:

If god would help me to get discharged from the dishonor of the army, I would come and stay permanently.

[...] When my leave expires, I will try to get into the hospital in Chania, in order to get the leave from there. ${ }^{\text {xxii }}$

Bearing in mind Karyotakis' own experience of the army, his correspondence and the date of his first recruitment, in

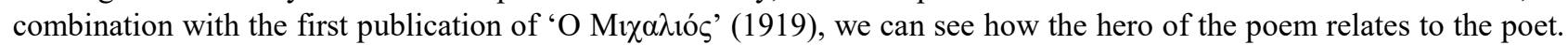
When Karyotakis wrote the poem, he was inspired by his own experience. The similarity between Michalios and Karyotakis is evident. They both want to avoid their military obligation, showing clearly their opposition to it: Karyotakis by looking for possible ways of a permanent discharge, and Michalios by saying repeatedly that he wants to return to his village. Thus, Michalios may be seen as Karyotakis' alter ego. Karyotakis saw this village boy as an ideal case to show his own attitude to the army. In fact, the poem, and especially the end, is ironic, as Benatsis mentioned. However, the target of Karyotakis' satire is not village boys but himself and the overall idea of army.

The biographical background of the poem is helpful, because it provides us with useful material about the character of the poem. When Benatsis said that the relation of 'part to whole' denotes irony, he left an open window for further discussion. There is some difference (Princeton Encyclopedia 1993) between irony ${ }^{x x i i i}$ and self-irony; and Benatsis speaks about irony because he set aside any biographical information. Irony implies that the poet sees Michalios as the object of his satire. But focusing on the poet's own experience, we see that Karyotakis attacks himself and the army and he does not denote his antipathy for village boys or any other category of people. Thus, the poem is self-satire. ${ }^{\text {xiv }}$

\section{Karyotakis' Disease}

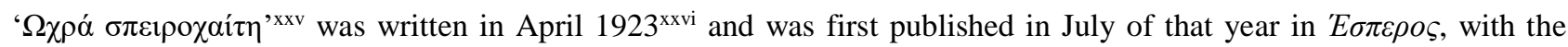

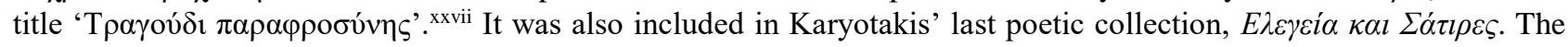
poem consists of five stanzas of four lines and is written in iambics, rhymed ABAB. The title of the poem denotes syphilis and specifically the scientific name of the virus. The poem outlines how a man is infected by syphilis and the results of the disease for him. Karyotakis describes the whole process in a clearly ironic manner.

In the first stanza, the poet mentions scientific books, in combination with a woman who satisfies men's needs. Although he does not openly say that we have to do with prostitute, the whole description implies such a woman:

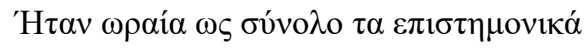

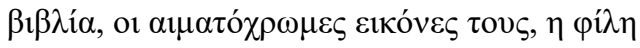

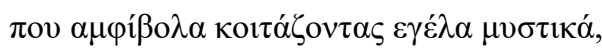

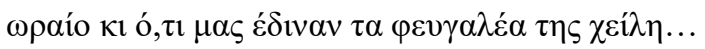

In the above lines, Karyotakis speaks about a woman who offers pleasure to several men, as he uses first plural person for men and third singular for the woman. Moreover, the phrase $\alpha \gamma o \rho \alpha \sigma \mu \varepsilon \dot{v} \eta \eta$ $i \lambda \eta$ ('hired girl', Reader and Taylor 2006) $)^{\mathrm{xxviii}}$ suggests that we can see this woman as a prostitute. Also the reference to scientific books surely denotes medical books, with information about the disease and perhaps advice about a possible treatment. A key phrase, showing the satirical climate, is the prostitute's laugh at the time of intercourse. Her attitude suggests that she knows the likely results for a man after intercourse with her. In this way, Karyotakis makes his satire evident from the very beginning, through the prostitute who secretly laughs and mocks the men who come to her.

In the next stanza, we have the description of a man's psychological condition after his infection: 


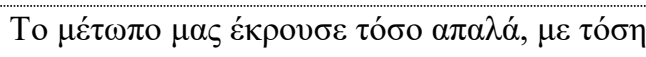

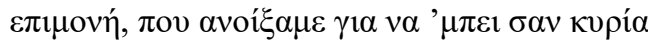

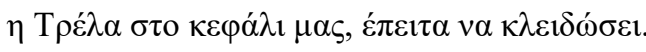

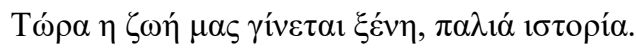

The phrase 'Madness in our heads' is likely to be seen as one of the results of the infection, as syphilis was not a curable disease when the poem was written, and it caused a kind of mental disease to patients. In addition, Karyotakis mentions that the life of those who are infected by syphilis becomes completely different; like an old story. These people understand now their self-destructive mistake and what is coming next: possible death. A similar climate appears in the first half of the third stanza:

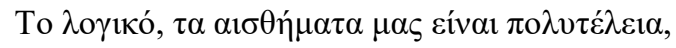

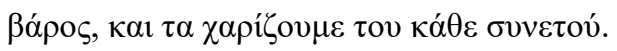

The poet asserts that logic and feelings is a luxury for them; this is obviously another effect of the disease which accompanies the madness of the previous stanza.

From this point, the poem becomes an evident satire, which is directed at two ways; towards God and infected people:

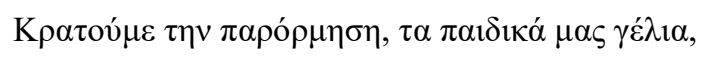

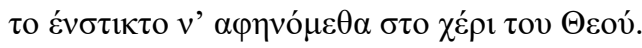

The poet states that syphilis sufferers live for the rest of their lives with childhood laughter, leaving themselves in God's hand. The phrase implies a kind of complaint against God, since the poetic ego feels wronged and alone. What we see here, it is possibly a kind of custom to believe in God rather than true faith. Besides, the use of the word 'instinct' denotes that people turn to God because of insecurity and not because of real faith. This is the case for someone who has syphilis too.

This is more evident in the next stanza, where we have the juxtaposition of comic elements and religious references:

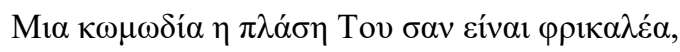

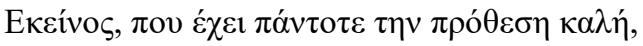

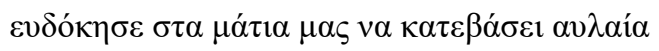

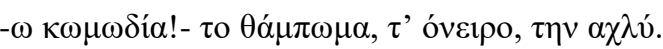

In the above lines, the poet says that God's creation seems like comedy, when it is characterized by horror ( $\varphi \rho i k \eta)$. Although God has always good intentions for people, in the case of those who have syphilis, he wanted something different: to close their eyes. According to the poet, this situation is a comedy and the word is repeated in the last line of the stanza, directing his satire at God.

In the last stanza of the poem, the author returns to the woman who is responsible for the condition of the infected men:

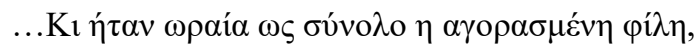

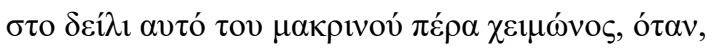

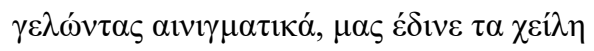

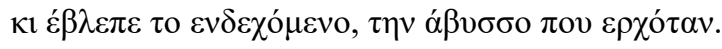

The atmosphere is very close to that of the first stanza, since we have very similar phrases. Again, the woman seems to know what follows after intercourse, as she laughs enigmatically: the infection. Here, irony is expressed by a prostitute to men. Her enigmatic laugh implies an irony and a kind of mockery, while the word 'abyss' has religious meaning as the opposite of heaven. This is the punishment of God for the people who have syphilis. Though God is good for all people, as the poet suggested in the previous stanza, he sends syphilis sufferers to hell.

The content of the poem makes us think why the poet would write a poem with such a theme, while the reference to scientific books shows some interest in the disease. As we are going to see, the poet's biography enlightens the poem. In a discussion with Savidis, Theodoros Karyotakis (a cousin of the poet) said that the poet did contract syphilis, but only in 1926 during a visit to Romania (Savidis 1989). ${ }^{\text {xxix }}$ But evidence shows that Karyotakis had syphilis several years before the date given by his cousin. Karyotakis' editor, Petridis (2001), writes in his introduction, that in 1922 when Polydouri asked Karyotakis to marry her, the latter told her that he was infected by syphilis. ${ }^{\mathrm{xxx}}$ Also, as Reader and Taylor suggest (2006), it is very likely that Karyotakis was infected by the disease during his years in Athens as a student (1914-1919); and certainly before his meeting with Polydouri in 1922 (Reader and Taylor 2006). ${ }^{x x i}$ Inevitably, the poet was indeed suffering from syphilis, when he wrote the poem.

It is interesting to look at the correspondence which gives us further material, and particularly Polydouri's letter to Karyotakis of 12 October 1922:

Come on Takis, let us live together... you will see how sweet and comforting, I will be for you. It is not difficult, not difficult at all. I know all the obstacles and all the consequences. [...] We will not have any children of course -are you laughing? This is so easy and usual nowadays. Besides, I have my own doctors who will do everything for me. [...] If you knew how it hurts me to think that you, the ideal man with divine 
soul, treat these dirty women, who spoiled your health, in that way... how it hurts me!... [...] In any case, don't believe -I implore you- that you would hurt me just because you are sick. [...] It is enough for me not to want and I do not want- to be infected by you; I assure you. ${ }^{\text {xxxii }}$

The above letter clearly shows that Karyotakis told Polydouri about his condition in 1922. ${ }^{x x x i i i}$

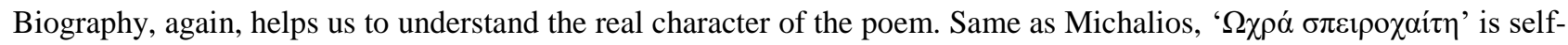
satire. Karyotakis does not want to mock people with syphilis. He wants to mock himself and he is the object of his own satire. Syphilis became a kind of obsession in Karyotakis' mind; and this is what we have in ' $\Omega \chi \rho \alpha$ o $\sigma \pi \varepsilon i \rho o \chi \alpha i t \eta '$ ' the description of his own obsession. When the poet uses first person narrative is not just a poetic technique, but a poem about himself. Also, he refers to scientific books, because of this obsession, as it seems that Karyotakis read books in order to learn more about his condition. ${ }^{\text {xxiv }}$

\section{Karyotakis as Government Clerk}

Karyotakis' worked for the government from 1919 to the end of his life in 1928; nine years in a relatively short life, as Karyotakis died at the age of 32. On 9 November 1919, he was officially appointed as first class officer of the Ministry of Internal Affairs in Thessalonica. In 1920, he was appointed to Syros and after a while to Arta. In 1921, he moved to Attica and in 1923 he left the Ministry of Internal Affairs and was appointed at the Ministry of Welfare, in order to stay in Athens. Finally, in 1928 and after a disagreement with his superiors in the government, Karyotakis was sent to Patra and then to Preveza. ${ }^{\mathrm{xxx}}$

In a letter to his friend Sakellariadis, on 15 November 1919, Karyotakis writes:

Besides, my life is more boring and miserable than I used to believe and you imagine. Cry for me, Charilaos, cry for me, my friend. I am starting to curse the moment I decided to leave. ${ }^{\mathrm{xxxvi}}$

The letter was written just some days after Karyotakis' arrival in Thessalonica; he feels bored and regrets for his career.

In another letter to Sakellariadis, in May 1925, Karyotakis sees his career in government with irony. The atmosphere is not different from that of the previous letter, as Karyotakis presents his life really boring:

I offer my high service to the Ministry of Health, Welfare and Assistance, of course. [...] In regard with all the rest, home and work. My life is a fine clock (as we are accustomed to say), which God has still the kindness to wind up every morning. xxxvii

As we can see, Karyotakis does not seem happy at all with his career as government clerk.

Nevertheless, Karyotakis was really popular among his colleagues. On 13 January 1928, he was elected to the executive board of his Civil Servants Union, while his poem ' $\Delta \eta \mu$ ó newspaper of the union: on 19 February 1928 and on 5 September 1929. xxxviii On 14 February 1928, he was the leading rebel against an embezzlement of funds (Dounia 2001). ${ }^{\text {xxix }}$

Karyotakis' active role in the clerks' movement was just one reason for his punitive transfer to Preveza, but the main cause was an article against the minister Kirkos. According to this article (Baloumi 1988) which was published

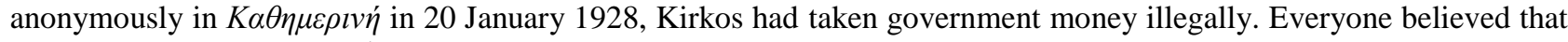
the author was Karyotakis. ${ }^{\mathrm{xl}}$

Another important element showing Karyotakis' active role in clerks' actions was the publishing of another article

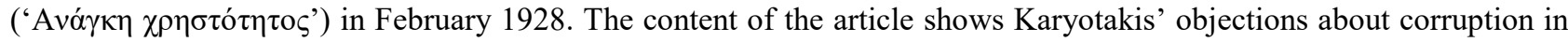
the government. ${ }^{\text {xli }}$ Papakostas (1912), who re-published the article with some commentary, mentions that it shows knowledge of several problems, such as tax evasion and the exploitation of people through additional taxes. ${ }^{\text {lii }}$

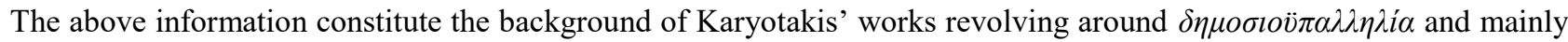
the poem ' $\Delta \eta \mu$ ó $\sigma 101 v \pi \alpha ́ \lambda \lambda \eta \lambda$ o' xliii, which is, again, self-satire. Apart from ' $\Delta \eta \mu$ ó

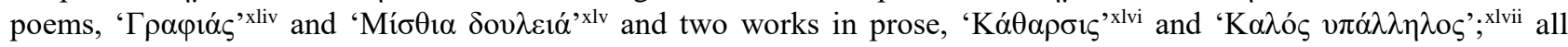
related to the civil service.

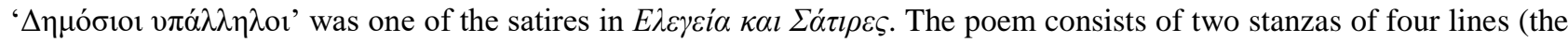
first and the second) and two stanzas of three lines (the third and fourth) and is written in iambics. In general, it describes the boring life of government clerks.

In the first stanza, the poet draws a parallel between the clerks of the poem and batteries, in a satirical manner:

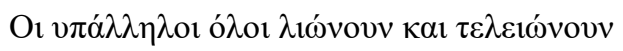

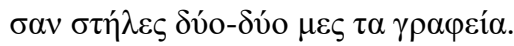

(Н

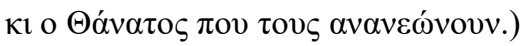

According to the poet, 'all the clerks get drained and end up in their offices' (Reader and Taylor 2006) ${ }^{\mathrm{xlviii}}$ two by two, like pairs of batteries. Their sources of re-charge will be the State and Death, which are characterized by the poet as 'electricians' in a clearly ironic manner. The poet makes government clerks seem as inanimate creatures, entirely dependent on the State and Death.

Although in the Greek text we do not have the word 'battery', this is what the word $\sigma \tau \dot{\eta} \lambda \varepsilon \varepsilon$ suggests (Reader and Taylor 2006). ${ }^{\text {xlix }}$ In their commentary, Reader and Taylor provide us with useful information about the reference to 'two by 
two'. They mention that we should focus on some historical explanations to see the meaning and explain: 'in Greek government offices of the 1920's for reasons of space it was typical for two clerks to sit facing each other at one large double desk'. ${ }^{1}$

In the second stanza, the poet describes a usual day of government clerks:

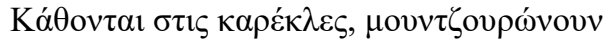

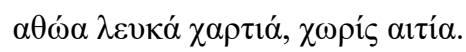

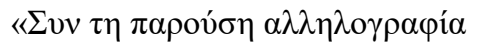

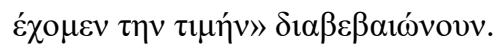

The clerks appear to have no real duties, since their only action is to write on blank sheets of paper. Their responsibilities are limited to such actions. They spend their time needlessly. By using the parenthetic phrase $\sigma v v \tau \eta$

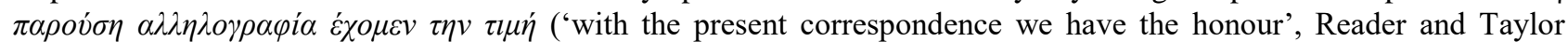
2006), ${ }^{\text {li }}$ in direct speech, the poet gives a strong satirical element. Although they do not have real work, since they just write irrelevant things on blank sheets, the grandness of their speech in katharevousa shows that they see their position as something really important.

This speech in katharevousa in the poem, obviously ironic, is reminiscent of the irony in Karyotakis' letter to Sakellariadis. lii Like the phrase of the poem ('we have the honour'), in his letter Karyotakis gives his speech grandness, as well ('I offer my high service... of course').

In the third stanza, the poet refers ironically, again, to clerks' honour as their only concern:

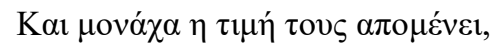

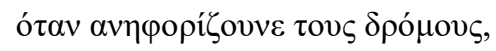

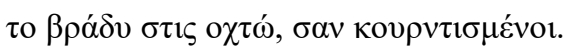

When they go up the streets, presumably on their way home, they have only their honour. The similitude 'like wound-

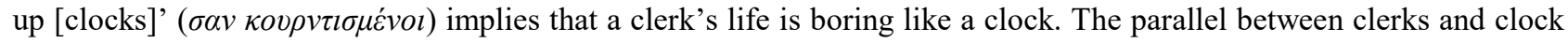
recalls, again, Karyotakis' letter to Sakellariadis, as he wrote that his life is like a fine clock.

Moreover, the choice of the time (eight o' clock) is not coincidental. In his letter on 16 September 1927, Karyotakis writes to Sakellariades: "I entered the well-shaft, again. Since yesterday, we have new winter timetable. We leave at eight o' clock every night.,"liii

This is an everyday situation for Karyotakis, since it is the time that he usually goes home, as do the clerks of the poem. In the last stanza, the poet describes clerks' thoughts:

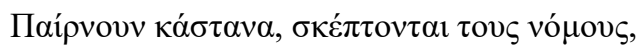

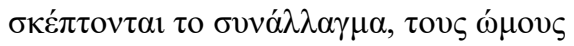

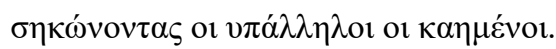

Although they think about regulations and exchange rate, there is nothing that they could do. The fact that they are unable to change the situation is shown by the shrug of their shoulders; an action that shows they are powerless. The last description - 'these poor clerks'- that is used by the poet shows that they are unable to do anything. Although there is a sense of mercy, the climate is mainly satirical.

Clerks' interest in regulation and exchange rate is reminiscent of Karyotakis' interest in the article 'Avó $\gamma \kappa \eta$ $\chi \rho \eta \sigma \tau$ ó $\tau \tau \tau \varsigma^{\prime}$ '. Like the clerks of the poem, Karyotakis sees the necessity for change. However the only possible action for him is to write an article. The clerks of the poem think about regulation and rules, while Karyotakis thinks about taxes and related matters. Although the article was written approximately one year after the poem, we can assume that Karyotakis thought about such things many times before the publication of the article and, certainly, during the writing of the poem.

Baloumi (1988) who focuses on Karyotakis' works in prose asserts that the environment of government administration was firmly associated with Karyotakis' own experience as government clerk, and that the poet saw -himself- the

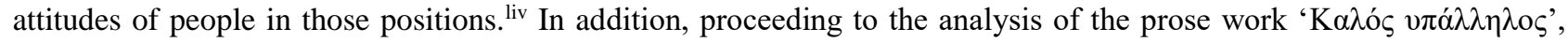
Baloumi believes that Karyotakis satirizes himself ( $\sigma \alpha \rho \kappa \alpha ́ \zeta \varepsilon l \alpha v \tau o \sigma \alpha \rho \kappa \alpha \zeta o ́ \mu \varepsilon v o \varsigma) .{ }^{\mathrm{lv}}$

Among the other works of Karyotakis on government clerks, 'Ká $\theta \alpha \rho \sigma \iota \varsigma$ 'lvi is an interesting one. This prose work was written when Karyotakis moved from Athens to Patra and then to Preveza. In 1928, the Greek government wasted the money which was meant for reestablishment of refugees in Greek territory. Articles in newspapers (Reader and Taylor 2006) dealt with the misappropriation of funds, embezzlement and bribery. ${ }^{\text {lvii }}$ Karyotakis was the secretary of a committee, whose goal was the proper allocation of money. 'Ká $\theta \alpha \rho \sigma \iota \varsigma$ ', which was not published while Karyotakis was still alive, reflects these events:

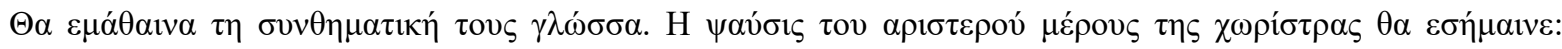

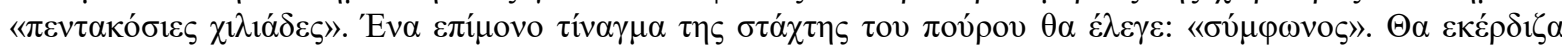

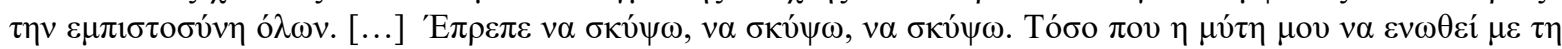

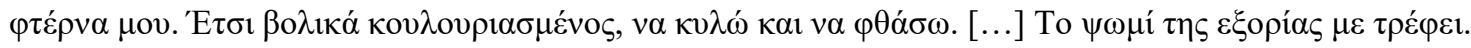


In the above lines, Karyotakis describes what he should do to enjoy his superiors' favour: participate in this corruption. He gives an ironical description of the government, characterizing the place of his work as exile. One could say the exile is Preveza and maybe Patra as the interim stage.

\section{The Experience of Preveza}

Karyotakis' days in Preveza was possibly the most depressive period of his whole life, as the poem ' $\Pi \rho \varepsilon \beta^{\beta} \varepsilon \zeta \alpha^{\text {'lviii }}$ and his correspondence suggest. During his stay in Preveza, Karyotakis' melancholy and pessimism were very strong and

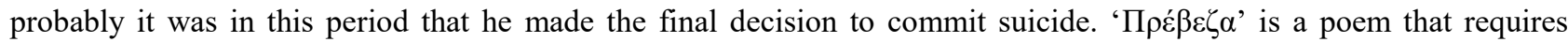
extensive knowledge of biographical details, if readers are to understand the meaning. There is ambiguous syntax and no obvious coherence.

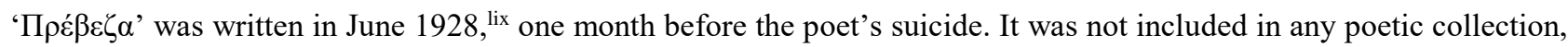
but both Savidis (2001) and Petridis (2001), included it in their editions of Karyotakis' works. ${ }^{1 x}$ ' $\Pi \rho \varepsilon ́ \beta \varepsilon \zeta \alpha$ ' consists of six stanzas of four lines and is written in iambics. Again, we see the rhyme scheme ABAB. In the first stanza, the poet focuses on jackdaws and women in despair:

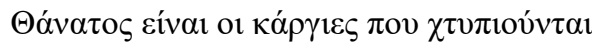

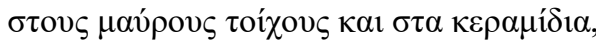

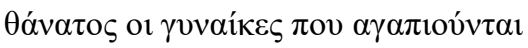

$$
\begin{aligned}
& \kappa \alpha \theta \omega ́ \varsigma \text { v } \alpha \alpha \theta \alpha \rho i ́ \zeta o v v \varepsilon \kappa \rho \varepsilon \mu \mu v ́ \delta \alpha^{\text {lxi }}
\end{aligned}
$$

In the first two lines, we have the appearance of a specific kind of black birds, jackdaws, which beat themselves against walls and roof-tiles. In comic vein, the poet depicts the birds as desperate. Instead of their usual function (flying), the birds seem to be suicidal. Moreover the colour of birds and wall is black to suit the pessimistic climate of the work.

In the last two lines, the poet turns to women. Although intercourse is something which can offer pleasure and satisfaction, in these lines it becomes the opposite: 'women who make love as if they were peeling onions' (Reader and Taylor 2006). ${ }^{\text {lxii }}$ The scenography is rather comical, while at the same time the poet describes the world as dark. He makes intercourse a negative process for women by presenting it as a household chore, like peeling onions. In that way, it seems more like violation, than love.

In the second stanza, the word 'death', which appears in the first three stanzas, is used by the poet to describe natural elements:

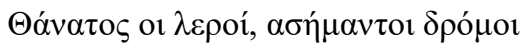

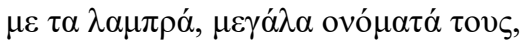

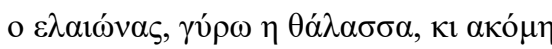

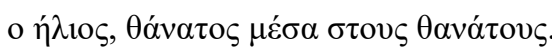

In the poet's mind the 'grimy' and 'insignificant streets', 'the olive grove' (Reader and Taylor 2006), ${ }^{\text {liii }}$ the sea and the sun are synonymous with death; they are 'death among deaths'. Every element in nature is reason of pessimism and sadness. Although one could say that it is common for the sea to be associated with nostalgia, in this poem it becomes a step before death. Even the sun which is the source of light and revival becomes symbol of death. Although roads have brilliant and great names, for the poet they are insignificant.

In a letter to Polydouri, in June 1928, Karyotakis describes Preveza. The description is very close to the poem:

I am sitting in the office and watch a ribbon of sea, a sycamore, a shaft and some other insignificant things. [...]

Preveza is just an ugly village. It is almost below sea-level; it is invisible. You think that it hides itself because of its pitiful state. [...] Besides, there is no single [road] longer than 30 metres and they all have tiny signs with brilliant names: France Road, George I Road, Alexander the Great Road, etc. [...] In regard to the inhabitants, ha! They are first cousins of Barbagiorgos: 'good tall olive trees'. xiv

As we can see, the vocabulary of the letter is identical with the poem. First, the reference to the great names of roads in Preveza appears in both. Secondly, the olive grove of the poem could be an alternative of people, who are described by Karyotakis in the letter as tall olive trees. Also, the sea is another common element, as in the poem Karyotakis speaks about the sea in all directions, while in his letter he mentions that he can see a ribbon of sea from his office. Also in a later line of the letter, he says that Preveza is below sea-level.

In the third stanza, Karyotakis focuses on two categories of people who should be models of justice and learning: a policeman and a teacher:

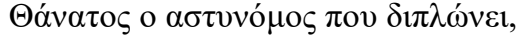

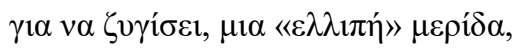

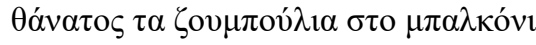

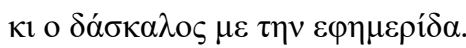

The question that emerges is: what is the role of the policeman 'who wraps up an insufficient serving in order to weigh it', and the 'teacher with the newspaper' (Reader and Taylor 2006)? ${ }^{\text {lxv }}$ Benatsis (2004) asserts that the policeman is responsible for justice, protecting people from cheating and insufficient serving. He also mentions that the comic 


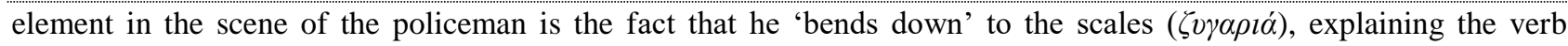
$\delta \iota \pi \lambda \dot{\omega} v \varepsilon l$ as a reference to the policeman's body, synonymous with yé $\rho v \varepsilon l$ and meaning 'bends down'. He finally concludes that we have a contradiction between the erect body ( $\varepsilon v \theta v \tau \varepsilon v \varepsilon \dot{s} \varsigma \sigma \dot{\omega} \mu \alpha)$ which symbolizes bravery $(\lambda \varepsilon \beta \varepsilon v \tau i \alpha$ ) and the humped body ( $v \nu \rho \tau \dot{\sigma} \sigma \dot{\mu} \mu \alpha$ ) which is symbol of misery. Benatsis believes that the verb $\delta \imath \pi \lambda \omega \dot{v \varepsilon l}$ of the poem refers to the policeman's body and here is the comedy of the scene, since he cannot keep his body erect. ${ }^{\text {Ixvi }}$

Nevertheless, Benatsis' hypothesis is misleading. Reference to some biographical details makes clear that the verb $\delta \imath \pi \lambda \omega \dot{\omega} \varepsilon l$ means 'wraps up' and does not refer to the body of the policeman but to the serving ( $\mu \varepsilon \rho i \delta \alpha)$, as we assume from a letter of Karyotakis to a relative in June 1928:

This is the latest news from Preveza. [...] The other day the magistrate took away, having first wrapped it up in a clear paper, the serving which they brought him at the hotel, because he thought that it was insufficient. He weighed it in the police station; he brought it back again; he unwrapped it, put it on a plate and ate it. ${ }^{\text {lxvii }}$

Beyond the obvious similarity between the above extract from the letter and the description of the policeman in the poem, the explanation of $\delta \imath \pi \lambda \omega v \varepsilon \varepsilon$ is very important: in the letter, Karyotakis uses the Greek verb $\varepsilon \tau \dot{\imath} \lambda \imath \xi \xi$ to denote the wrapping up and $\varepsilon \xi \varepsilon \delta i \pi \lambda \omega \sigma \varepsilon(\varepsilon \kappa+\delta l \pi \lambda \omega v \omega)$ for the unwrapping up. The subject of the verbs is the magistrate and the object the insufficient serving. In any case, the verb is used by the poet to show the process of the wrapping up of the serving by the policeman. As a result, the correct syntax is 'the policeman wraps up the serving' and not 'the policeman bends down' as Benatsis suggests.

At the beginning of the fourth stanza, there is a series of three words that prompts enquiry about its meaning:

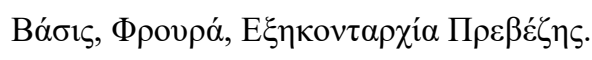

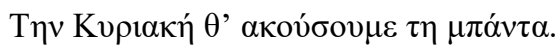

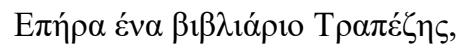

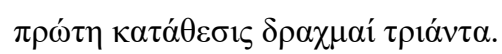

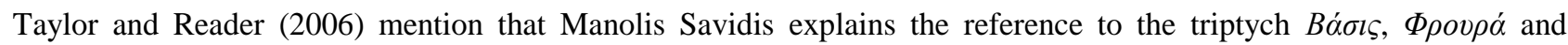

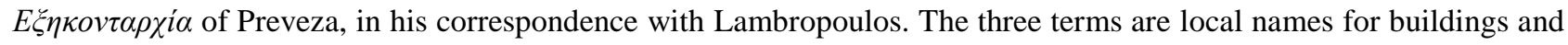
Karyotakis names them in the order that one sees them walking along a part of the waterfront in Preveza (Reader and Taylor 2006). ${ }^{\text {Ixviii }}$

Also, the phrase 'first deposit' alludes to a real event. There is evidence in a letter of Karyotakis to his father in July 1928:

If Thanos (Karyotakis' cousin) knows that the shares of the Bank of Greece will increase in value, let him register for me the amount of 2.500 or 3.000. I have this money from a viaticum etc, but I deposited it here, in the branch of National Bank. ${ }^{\text {lxix }}$

Sakellariadis (1971) asserts that the poet made his first and only deposit at a bank, mentioned in the letter, when he was in Preveza. ${ }^{\text {lxx }}$ In regard to the number 'thirty' which is the amount of the deposit, one could say that it is an indirect allusion to Karyotakis' age at the time. When Karyotakis wrote the poem, he was approximately 30 years old (actually 32). ${ }^{\mathrm{Ixxi}}$

In the fifth stanza, the poetic ego appears to walk along the wharf and refers to the arrival of a ship with raised flag; possibly, according to the poem, the Governor is coming:

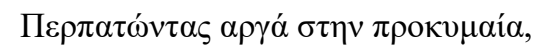

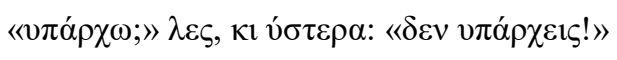

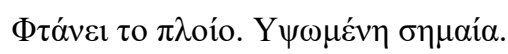

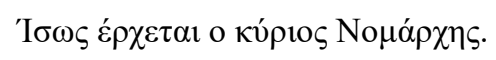

A letter that Karyotakis writes to one of his relatives is also helpful:

The ship arrived decorated with flags. [...] When we saw it, there was great noise in the prefecture. The First Secretary was pacing nervously up and down. Who is it? The Governor? The General Officer or another personality? Eventually, it was ascertained that it was the Bishop of Ioannina (may you have his blessing). Then, we fell back into our narcosis. ${ }^{1 \times x i i}$

Focusing on the poem, Benatsis (2004) maintains that the Governor's arrival implies the arrival of one single person and not a group of people, concluding that there is a sense of isolation. ${ }^{1 x x i i i}$ But reading Karyotakis' letter, we can see that different meanings emerge.

In his letter, Karyotakis writes that after they realized that it was the Bishop of Ioannina arriving and not a person such as the Governor for inspection, all the government clerks relaxed. This incident suggests that in the poem Karyotakis attempts to satirize the reaction of his colleagues, including himself, when they noticed the boat. The intention is not to denote isolation, but to satirize the clerks' fear of a possible inspection.

In the last stanza, the poet refers to a funeral and people's sorrow:

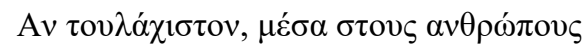

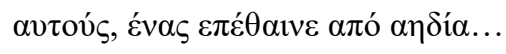




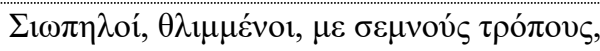

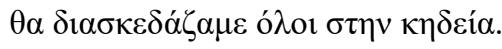

The poet mentions that if any of these people were to die because of disgust, then he and his companions would have fun. The irony is again clear, as Karyotakis turns a funeral to a situation of celebration.

\section{Conclusion}

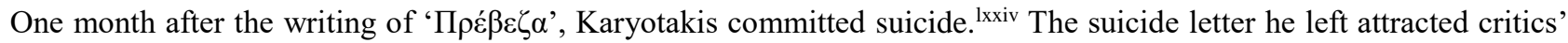
interest. In the letter, Karyotakis reveals his own 'tragedy':

It is time for me to reveal my tragedy. [...] I hate the vulgar action they attributed to me. I sought just its imaginary atmosphere, the last bitterness. I am not the appropriate person for this work. My whole past convinces me. [...] I am sorry for my parents and my brothers. [...] I was sick. [...] Please telegraph to my uncle, Demosthenis Karyotakis, to prepare my family... ${ }^{\text {lxxv }}$

Karyotakis really did suffer and this letter comes as a consequence of his painful life. Agelatos (1994) mentions that

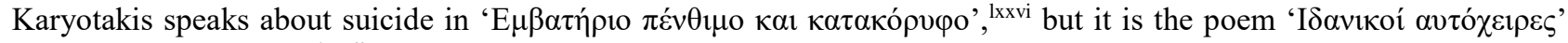
('Prospective suicides') ${ }^{\text {lxxvii }}$ which is most obviously connected with the issue of suicide.

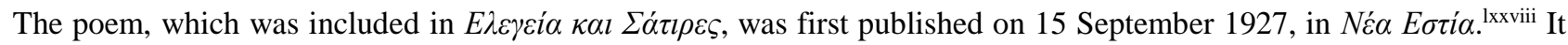
consists of five stanzas of four lines and is written in iambics; rhyme is again ABAB. In one of his articles, Savidis (1989) suggests that the suicide letter of Karyotakis consciously alludes to this poem. ${ }^{\text {lxxix }}$

The first similarity between the letter and the poem is the characterization of suicide's life as tragedy. In his letter Karyotakis says that 'it is time to reveal his tragedy', while in the second stanza of his poem he writes:

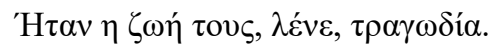

In both, the letter and the poem, the suicides see their life as tragedy.

Second, in his letter Karyotakis speaks about an untrue accusation against him, without making this clear. ${ }^{\mathrm{lxx}}$ In his poem, we have people who laugh at the suicides:

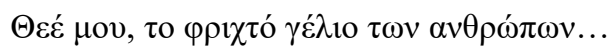

'The hideous laugher of people' (Reader and Taylor 2006) ${ }^{\mathrm{lxxxi}}$ alludes to the letter, as in the poem the suicides become the object of people's mockery, while in the letter Karyotakis presents himself as the 'victim' of a false accusation.

A third element which brings the poem close to the letter is the anxiety of the suicides about their relatives' reaction. In the letter Karyotakis expresses his sorrow for his parents and brothers and asks his uncle to prepare them. In the poem, we have:

$$
\begin{aligned}
& \text { 'О } \lambda \alpha \tau \varepsilon \lambda \varepsilon i ́ \omega \sigma \alpha v \text {. To } \sigma \eta \mu \varepsilon i ́ \omega \mu \alpha \nu \alpha \tau \text {, }
\end{aligned}
$$

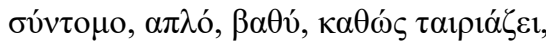

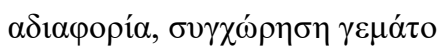

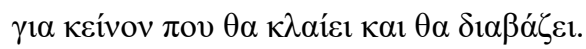

The suicides of the poem write a letter which is 'full of detachment and forgiveness for the one who will read and weep' (Reader and Taylor 2006). ${ }^{\text {lxxxii }}$

To the question 'what did Karyotakis think, when he wrote the poem', Savidis (1989) gives one possible answer, suggesting that 'we can imagine Karyotakis planning many times his own letter before the writing of this poem, and many others after that' ${ }^{\prime}$ xxxii Savidis (1989) implies that Karyotakis was always thinking of suicide and that possibly he had attempted suicide, before the final attempt on 21 July 1928. ${ }^{\text {lxxiv }}$ We do not have certain sources on that, apart from the 20 July 1928, the day before his suicide. Karyotakis went to the sea at Monolithi in order to drown himself. However, he did not manage to do so, and on the following day he bought a gun and shot himself. ${ }^{\text {lxxv }}$

Karyotakis' suicide could be seen as the last link in the evident relation between life and poetry, but in this case it is life (or death) which follows art rather than the other way round. As Agras (2001) said, Karyotakis was a 'real poet'; and as a 'real poet', he made his poetry a part of his 'body'. ${ }^{\text {xxxvi }}$ Besides, Karyotakis himself writes:

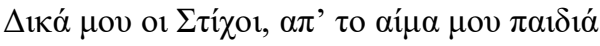

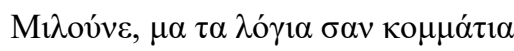

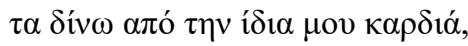

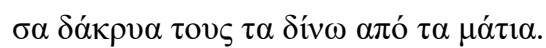

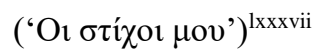

Concluding, in the analysis of Karyotakis' poems we need to examine his biography too, as life and poetry go together. Theories which deliberately avoid reference to external factors have indeed contributed to literary criticism and they are a great asset. Nevertheless, when dealing with poets like Karyotakis, biography is essential in the interpretation of the poems.

Beyond the works discussed in this paper, there are many others showing the close relation between life and poetry. For

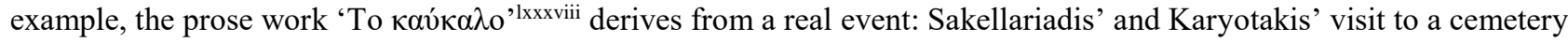


to take a skull from a small box (Reader and Taylor 2006). ${ }^{\text {lxxix }}$ Karyotakis describes the whole process and gives the

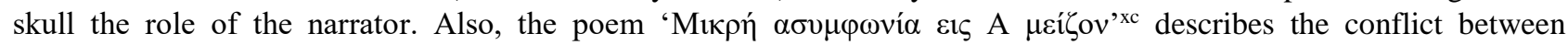
Karyotakis and the well-known poet, Malakasis. Biographical details show that the poem was written after Karyotakis attended a lecture by Malakasis and was disappointed by his behaviour. At the end of the lecture, when Karyotakis went

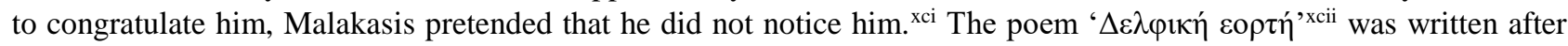
Karyotakis attended Sikelianos' attempt to revive Delphic festivals. ${ }^{\text {xciii }}$ Another example is the poem ' $\Sigma \tau \alpha \delta$ เo $\delta \rho o \mu i ́ \alpha$ ' ${ }^{\text {xciv }}$ Karyotakis refers to 'Vasileiou' (Reader and Taylor 2006), the name of the publishing house that held the remaining

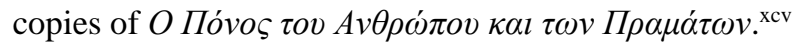

In his three poetic collections and also in several of his prose works, Karyotakis made his own experience the core of his poetry. The research could be enlarged in the manner of Robert Gittings' book (1962) John Keats: the Living Year, which traces Keats' life and writing over a period of twelve months. Gittings writes on the relation between life and poetry in Keats' work:

If we are to understand his poetry we must regard it not as lumber-room and store-house of what was past in his

life, but as a sensitive plate, reproducing what was present, an almost instantaneous development. His works form

a poetic diary of his daily life. ${ }^{\mathrm{xcvi}}$

This applies to Karyotakis too, without suggesting that Karyotakis wrote some sort of diary. But again, the obvious relation between life and work makes us see them together. Karyotakis' poetry is a dynamic whole which follows his life. As a result, parallel focus on poetry and biography is important for the full understanding of his poems.

\section{References}

Eagleton, T. (1996), Literary Theory: An Introduction (Oxford).

Eagleton, T. (2013), How to Read Literature (Yale University Press).

Eagleton T. (2013), The Illusions of Postmodernism (Oxford).

Gittings, R. (1962), John Keats: The Living Year: 21 September 1818 to 21 September 1819 (London).

Greenblatt, S. (2005), The Greenblatt Reader, ed. M. Payne (Oxford).

Karyotakis, K. (2006), Battered Guitars: Poems and Prose, tr. W. W. Reader and K. Taylor (Birmingham).

Kruczkowska, J. (2015), 'Who Gets Translated and Why? Anthologies of Twentieth-Century Greek Poetry in Poland', Journal of Modern Greek Studies, Vol. 33:1, pp. 105-125.

Morahan, S. (2012), 'Preveza', The Poetry Ireland, No. 108, pp. 77-78.

Preminger, A. and T. V. F Brogan (eds) (1993), The New Princeton Encyclopedia of Poetry and Poetics (Princeton).

Robson, M. (2007), Stephen Greenblatt (London).

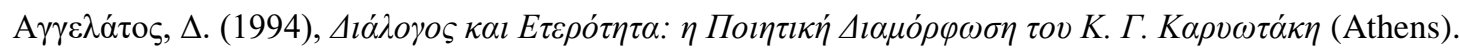

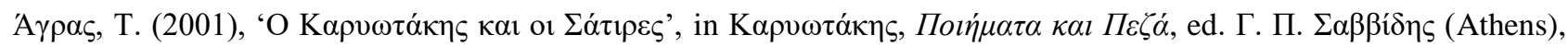
190-219.

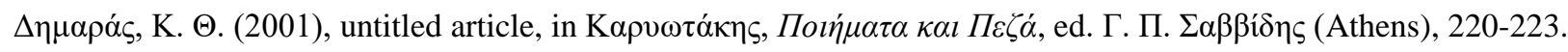

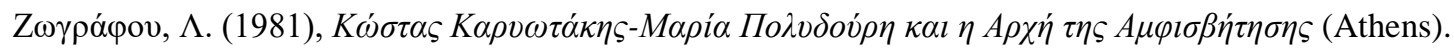

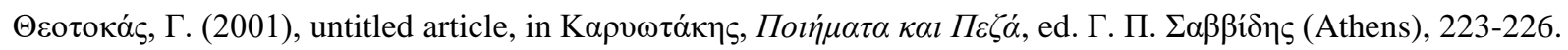

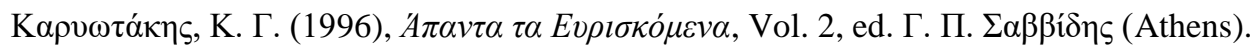

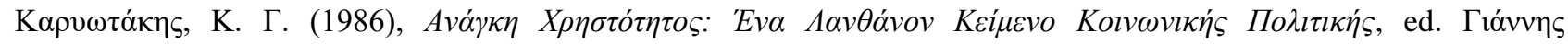

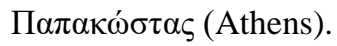

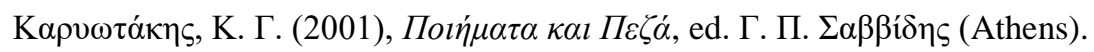

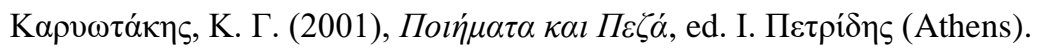

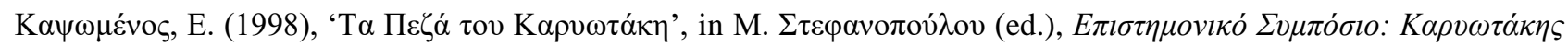

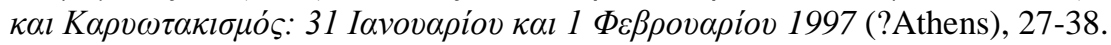

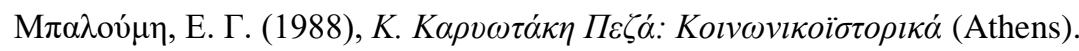

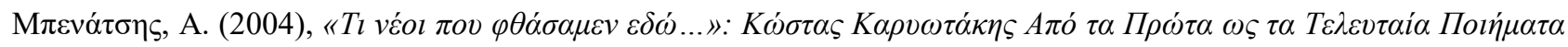
(Athens).

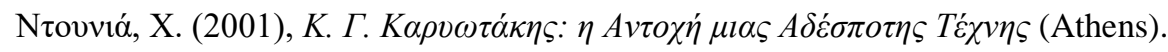

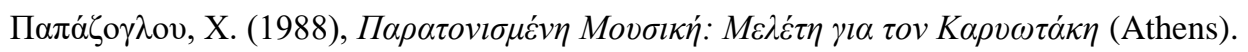

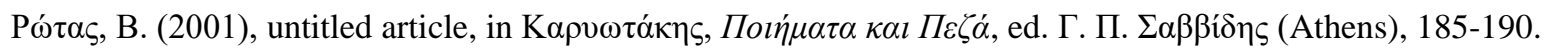

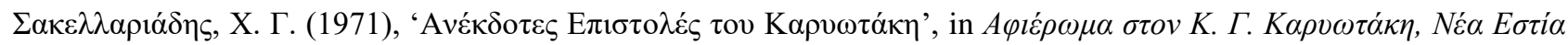
1065 (15 November 1971), 1537-1555. 


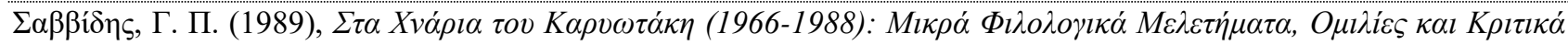

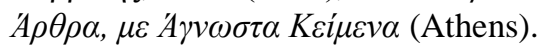

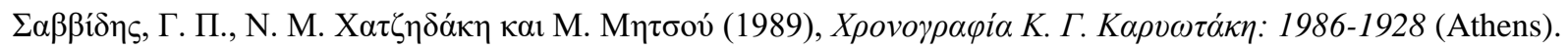

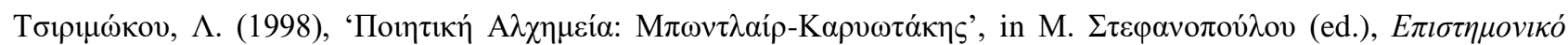

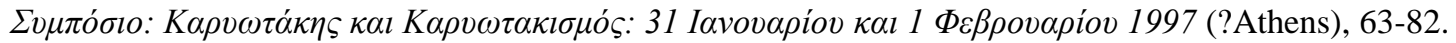

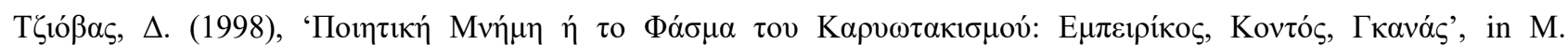

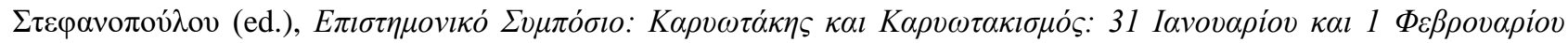
1997 (?Athens), 105-125.

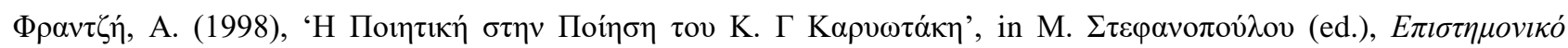

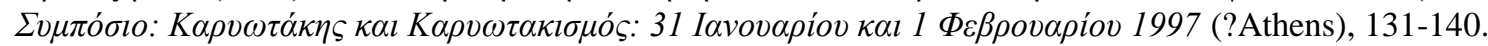

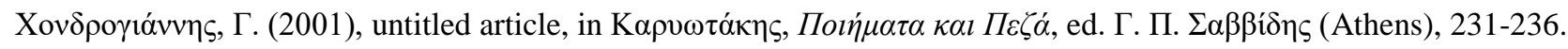

\section{Notes}

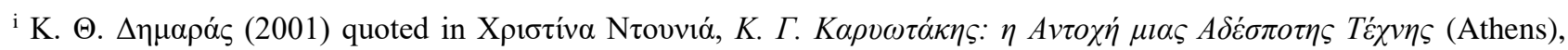
193-194.

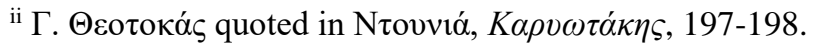

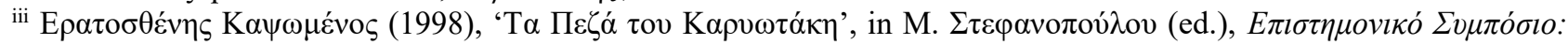

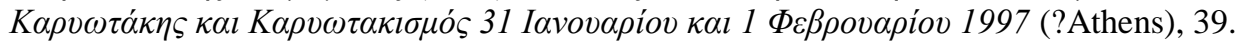

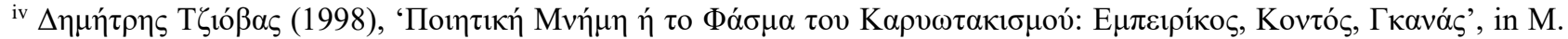

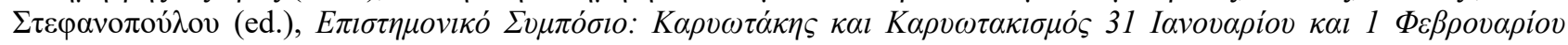
1997 (?Athens), 107.

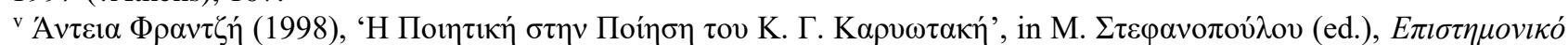

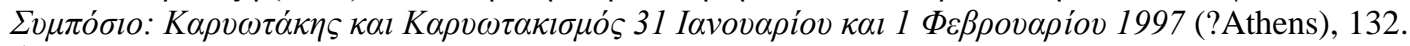

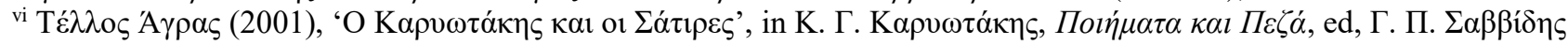
(Athens), 194-195. English translations are my own unless otherwise stated.

vii Terry Eagleton (1996), Literary Theory: An Introduction (Oxford), 196-197. See also Terry Eagleton (2013), The Illusions of Postmodernism (Oxford).

viii Eagleton, Literary Theory, 196-197. See also Terry Eagleton (2013), How to Read Literature (Yale University Press).

ix Stephen Greenblatt (2005), The Greenblatt Reader, ed. M. Payne (Oxford), 13. See also Mark Robson (2007), Stephen Greenblatt (London).

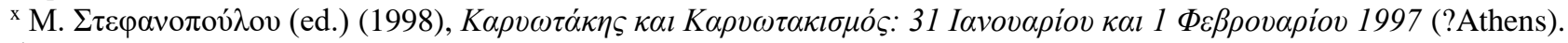

xi Joana Kruczkowska (2015), 'Who Gets Translated and Why? Anthologies of Twentieth-Century Greek Poetry in Poland', Journal of Modern Greek Studies, Vol. 33:1, pp. 105-125.

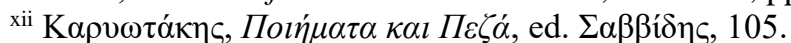

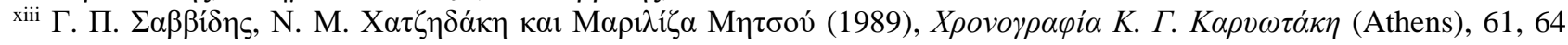
and 121, inform us about the dates of the publications: on 17 August 1919 under the title ' $\Sigma \tau \rho \alpha \tau$ ó $\varsigma$ '; on 13 October 1919

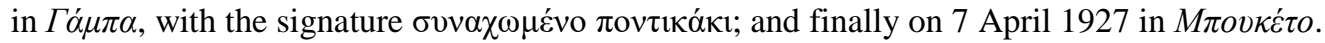

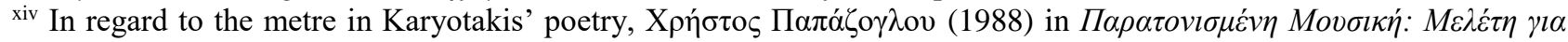

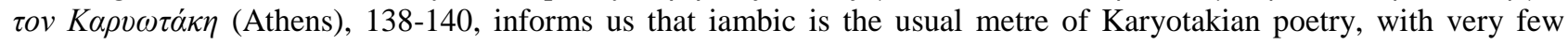
exceptions.

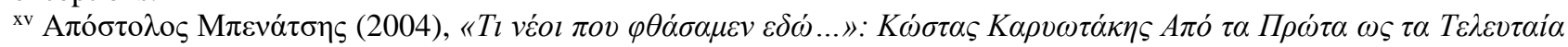
Поэиं $\mu \alpha \tau \alpha$ (Athens), 258-260.

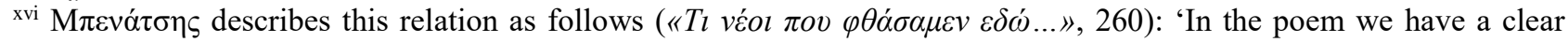
case of the relation: 'part to whole'. While the whole body of Michalios accepts the burial, his leg acquires the status of independent active person who denies and reacts. So, the contradiction between 'part to whole', except its ironical element, denotes inability for completion as well'.

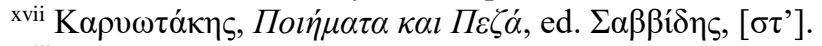

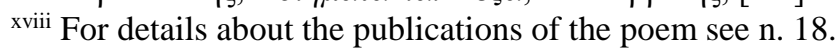

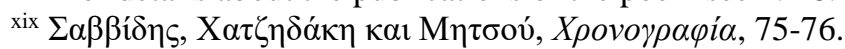

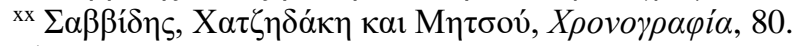

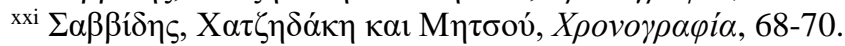

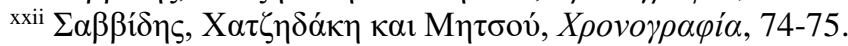

xxiii In A. Preminger and T. V. F. Brogan (eds) (1993), The New Princeton Encyclopedia of Poetry and Poetics (Princeton), 634, we can see that Classical rhetoricians identified different kinds of irony: sarcasm, meiosis, litotes (understatement), hyperbole (overstatement), antiphrasis (contrast), asteism and charientism (forms of the joke), chleuasm (mockery), mycterism (the sneer) and mimesis (imitation).

${ }^{\text {xiv }}$ In Princeton Encyclopedia, 1114, satire is defined a specific kind of literary genre in prose or verse which asserts polemical or critical outlook. Since Karyotakis makes himself the object of his own satire, then I could say that the poem is a self-satire.

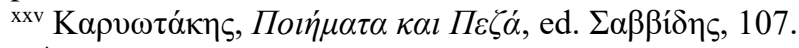

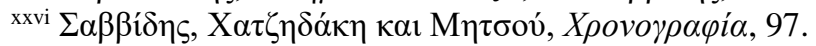

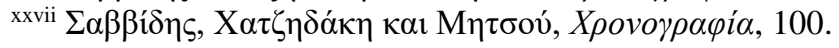


xxviii Tr. W. W. Reader and K. Taylor in Kostas Karyotakis (2006), Battered Guitars: Poems and Prose (Birmingham), 129.

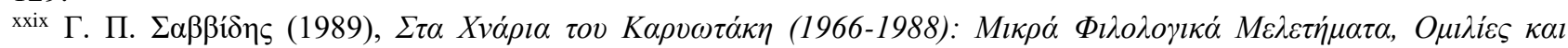

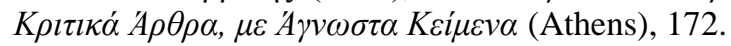

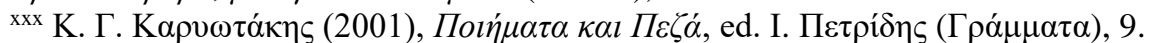

${ }^{x x x i}$ Reader and Taylor in Karyotakis, Battered Guitars, 207.

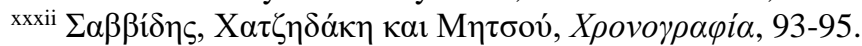

xxxiii Savidis also informs us that when the above letter was first published, Karyotakis' relatives asked for the revealing parts of the letter, where there is clear indication of Karyotakis' disease, to be deleted. This shows that the poet's relatives could not accept that Karyotakis had syphilis, which was a matter of shame in Greece of the 1920s ( $\Sigma \alpha \beta \beta i \delta \eta \varsigma$,

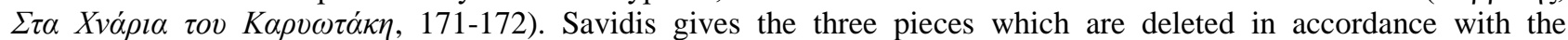
requirements of the relatives; these are the following: (a) 'who spoiled your health', (b) 'you are sick' and (c) 'it is enough for me not to want - and I do not want - to be infected by you'. A copy of the first, edited form of the letter

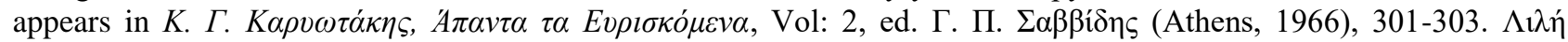
Z states that Polydouri did not believe him about syphilis. However, one year after the writing of the poem and two years after the letter, as Zographou mentions (98 and 104), Polydouri was informed that Karyotakis was one of the most frequent visitors of Doctor Foteinos, in order to get advice about his health. It was a period that Polydouri felt really shocked at her mistake in not believing him. In addition there are two other sources which confirm that Karyotakis indeed had syphilis: in 1928, he went to Paris to visit some venerealogists ( $\Sigma \alpha \beta \beta i ́ \delta \eta \varsigma, X \alpha \tau \zeta \eta \delta \alpha ́ \kappa \eta \kappa \alpha 1 ~ M \eta \tau \sigma o v ́$,

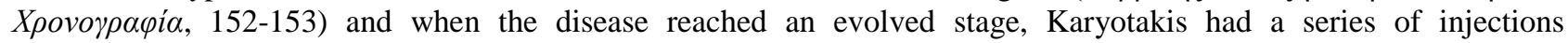

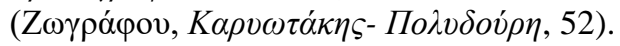

xxiv Karyotakis' obsession with syphilis is obvious also in the poem 'Y $\Sigma \alpha \beta \beta i \delta \eta \varsigma, 106)$. Karyotakis refers to the well-known poet Romos Filyras who lost his logic because of syphilis, while

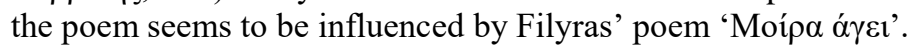

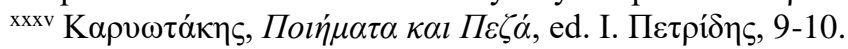

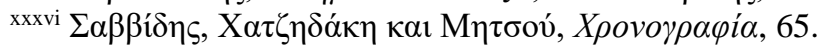

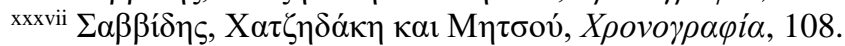

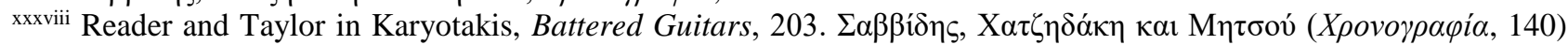
do not refer to the second publication of the poem in 1929, since their book stops at 1928, the year of Karyotakis' death.

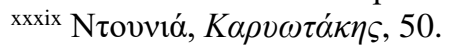

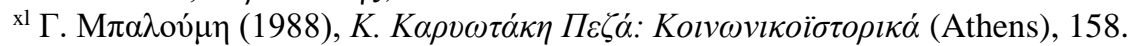

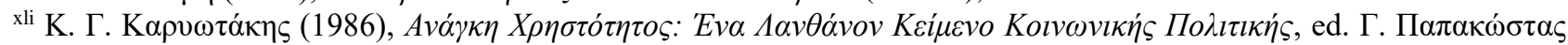
(Athens), 43-56.

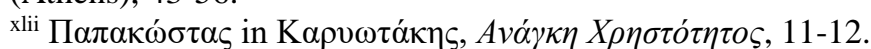

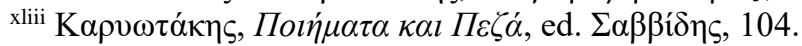

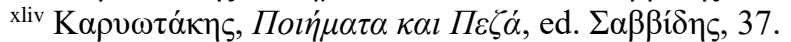

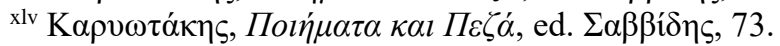

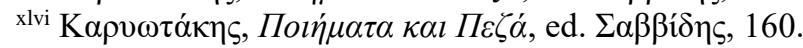

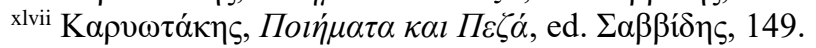

xlviii Tr. Reader and Taylor in Karyotakis, Battered Guitars, 126.

${ }^{x}$ lix In their translation, Reader and Taylor in Karyotakis, Battered Guitars, 126, interpret the word as battery, and

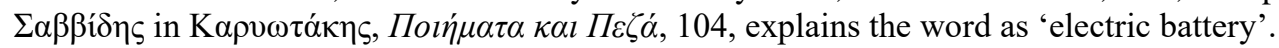

${ }^{1}$ Reader and Taylor in Karyotakis, Battered Guitars, 202.

li Tr. Reader and Taylor in Karyotakis, Battered Guitars, 126.

${ }^{\text {lii }}$ For the letter see p. 11.

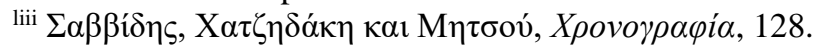

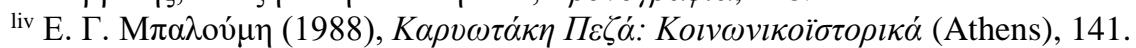

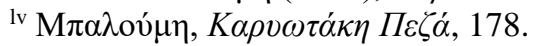

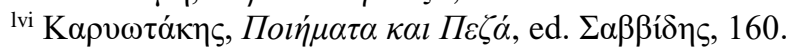

lvii Reader and Taylor in Karyotakis, Battered Guitars, 219.

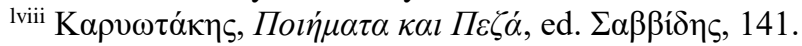

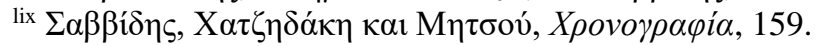

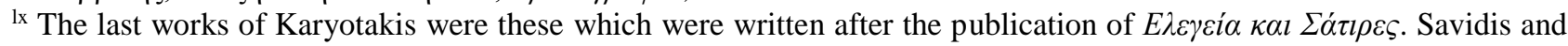
Petridis who published Karyotakis' complete poems included these poems in their editions.

lxi Another translation of the poem by Sorcha Morahan (2012) in The Poetry Ireland, No. 108, pp. 77-78.

lxii Tr. Reader and Taylor in Karyotakis, Battered Guitars, 143.

lxiii Tr. Reader and Taylor in Karyotakis, Battered Guitars, 143.

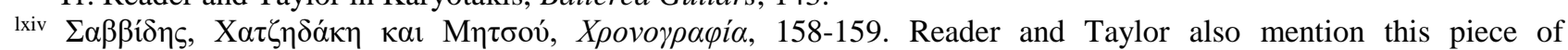
information in Karyotakis, Battered Guitars, 216.

lxv Tr. Reader and Taylor in Karyotakis, Battered Guitars, 143.

${ }_{\text {lxvi }} \mathrm{M} \pi \varepsilon v \alpha \dot{\tau} \sigma \eta \zeta$, «Tl véol $\pi$ ov $\varphi \theta \dot{\alpha} \sigma \alpha \mu \varepsilon v \varepsilon \delta \omega ́ \ldots », 311-312$.

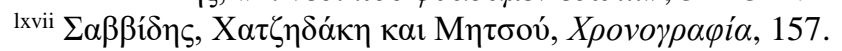

lxviii Reader and Taylor in Karyotakis, Battered Guitars, 216.

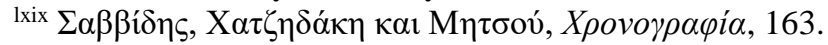




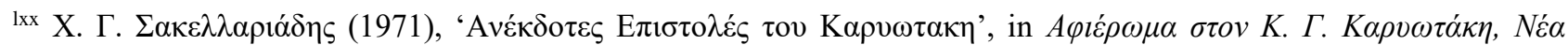

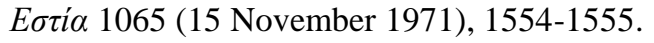

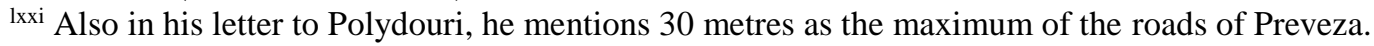

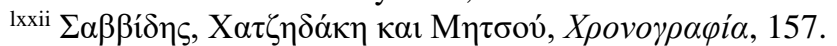

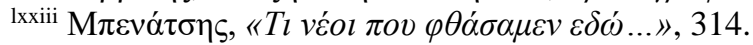

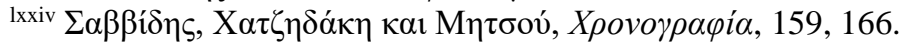

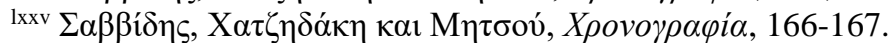

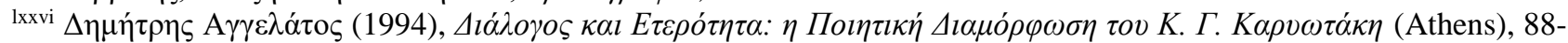
89.

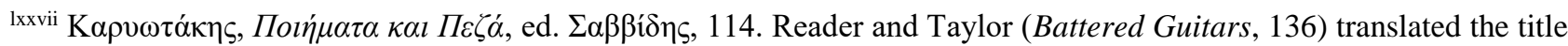
of the poem as 'Imagined suicides'. However, I think that focus on the content of the poem shows that 'prospective' explains more sufficiently the Greek word $\imath \delta \alpha v ı \kappa o i$.

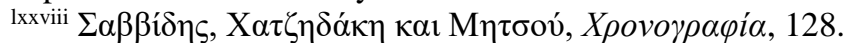

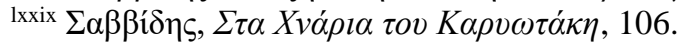

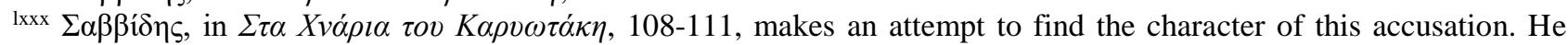
believes that possibly Karyotakis was accused of drug dealing. According to Savidis, there is some evidence in Karyotakis' works about poisons and drugs; and possibly this indication constituted the weapon of his accusers,

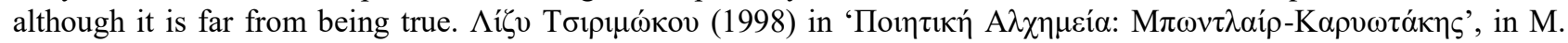

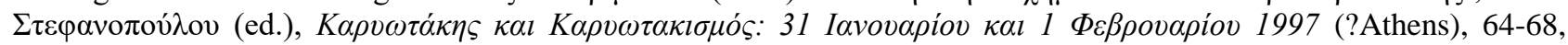
develops Savidis' surmise and also believes that it was very likely that Karyotakis was addicted to drugs, similar to some of the French poets he admired.

lxxxi Tr. Reader and Taylor in Karyotakis, Battered Guitars, 136.

lxxxii Tr. Reader and Taylor in Karyotakis, Battered Guitars, 136.

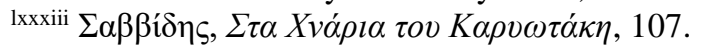

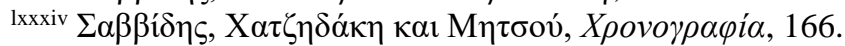

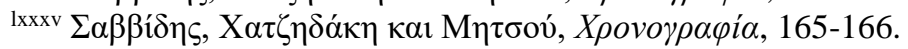

lxxxvi See p. 2-3.

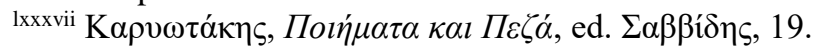

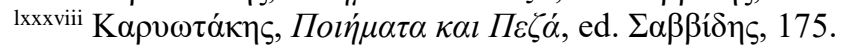

lxxxix Reader and Taylor in Karyotakis, Battered Guitars, 217.

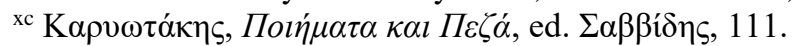

${ }^{\text {xci }}$ Reader and Taylor in Karyotakis, Battered Guitars, 210.

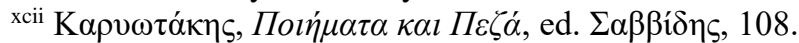

xciii Reader and Taylor in Karyotakis, Battered Guitars, 207.

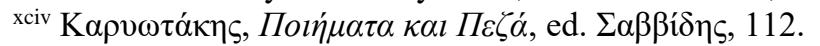

${ }^{\mathrm{xcv}}$ Reader and Taylor in Karyotakis, Battered Guitars, 212.

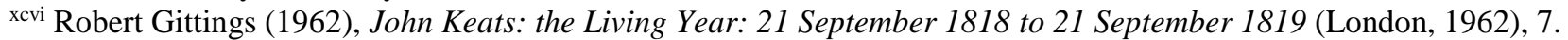

